\title{
Sosyal Bilgiler Lisans Programındaki Uygulamalı Derslere Yönelik Öğretmen Adayı Görüşlerinin İncelenmesi
}

\author{
An Investigation into Teachers' Opinions concerning Practical Courses within \\ the Social Studies Undergraduate Program
}

\begin{abstract}
İhsan ÜNLÜ* Erol KOÇOĞLU ${ }^{* *}$ Alpaslan $\mathbf{A Y}^{* * *}$

Öz: Sosyal bilgiler lisans programlarında yer alan uygulama dersleri, öğretmen adaylarının bilişsel ve devinişsel gelişimini temele alan derslerdir. Bu dersler öğretmen adaylarının mesleki yeterlilik gelişimine katkı sağladığı gibi, alan bilgisi yeterliliği üzerinde de oldukça etkili olduğu söylenebilir. Bu yüzden farklı alan uzmanları tarafından bu dersler yürütülmektedir. Bu çalışma, sosyal bilgiler dersi öğretmen adaylarının görüşlerine göre sosyal bilgiler lisans programında uygulamalı derslerde yaşanan sorunların tespiti ve bu sorunların mesleki yeterlik üzerine etkilerini araştırmayı amaçlamaktadır. Çalışma nitel araştırma yönteminin, durum çalışması deseni kullanılarak dizayn edilmiştir. Araştırmaya sosyal bilgiler öğretmenliği lisans programında öğrenim gören 10 öğretmen adayı katılmıştır. Amaçlı örnekleme yönteminin kullanıldığı araştırmada veriler odak grup görüşmesi tekniğiyle elde edilmiştir. Veriler içerik analizi yolu kullanılarak bulgulara dönüştürülmüştür. Elde edilen bulgulara göre öğretmen adaylarının uygulamalı derslerle ilgili kredi uyumsuzluğu, uygulamalı derslerin içeriği, programın yapısı ve öğretim üyesinden kaynaklanan sorunlar yaşadığı görülmüştür. Öğretmen adayları bu sorunların giderilebilmesi için çözüm önerilerinde bulunmuşlardır.
\end{abstract}

Anahtar sözcükler: Sosyal Bilgiler, Uygulama Dersleri, Mesleki Yeterlik, Sorun

Abstract: The practical courses within the social studies undergraduate program are based upon the cognitive and behavioural development of the candidate teachers. As well as contributing to the candidate teachers' professional competency, these courses are powerful instruments for competency in content knowledge, which is why these courses are conducted by experts in different areas. The aim of this study was to determine the issues in the practical courses in the social studies education program, and to discover according to the social studies education candidate teachers' opinion, the effects of these problems upon professional competencies. This qualitative study was designed as a case study. A total of 10 teacher candidates from the social studies education program participated in the study, selected in accordance with purposive sampling. The collected data was analyzed by content analysis. From the results obtained, the candidate teachers' reported they encountered problems relating to credit incompatibility, in the content of the practical courses, the structure of the program, and issues relating to the faculty staff. It was found that these problems played a role in the candidate teachers' professional competencies. Moreover, the candidate teachers' provided some recommendations to remove these problems.

Keywords: Social Studies, Practical Courses, Professional Competency

\footnotetext{
*Yrd. Doç. Dr., Erzincan Üniversitesi, Eğitim Fakültesi, İlköğretim Bölümü, Erzincan. ihsan-27@hotmail.com

** Yrd. Doç. Dr., İnönü Üniversitesi, Eğitim Fakültesi, İlköğretim Bölümü, Malatya. erolakademi@gmail.com

${ }^{* * *}$ Arş. Gör., Erzincan Üniversitesi, Eğitim Fakültesi, İlköğretim Bölümü, Erzincan. alparslanay@erzincan.edu.tr
} 


\section{Giriş}

Günümüzde eğitim kurumlarının yakalamaya çalıştı̆̆ı kalite standartları çok hızlı değişim göstermektedir. Kalite standartlarını geliştirmeye çalışan eğitim kurumları doğal olarak bir rekabet içerisine girmektedirler (Duman 1991). Eğitim ve diğer faaliyet alanlarında meydana gelen rekabet hiç şüphesiz bilgi çağının getirmiş olduğu bir gelişmedir. Bu durum ise kaliteyi ve profesyonelliği zorunlu kılmaktadır. Eğitim ortamlarındaki kalite ise öncelikli olarak öğretmenlerden ve öğretim programlarından hareketle şekillenmektedir. Bu sebeple eğitimde başarıyı sürekli bir hale getirmek ve toplumsal değişimi yakalayıp, ona ayak uydurmak gerekmektedir. Öğretim kademelerinin tümünde görülen bu güncellemeler öğretim programlarının; değişen ihtiyaçları, beklentileri karşılayabilmesi ve daha işlevsel hizmet sunabilmesi adına gerçekleştirilmektedir (Erçetin 2001; Özden 1999; Karslı, Yıldız, Akgün \& Cerit 2001). Bu durum aslında gelişmişlik düzeyine bakılmaksızın tüm ülkelerin önem verdiği bir konu haline gelmiştir. Eğitimde kalite standartları oluşturma arayışı yukarıdaki nedenlere bağlı olarak özellikle öğretmen eğitimi konusunda yoğunlaşmaktadır (Sözer 1991; Sezal \& Erkan 1997; Güven 2001).

Günümüzde öğretmenlik mesleğinin istenilen düzeyde öneme sahip olduğunu söyleyemeyiz. Bu durumun çok farklı sebepleri olduğu söylenebilir. Öğretmen yetiştirme programları, devletin öğretmen yetiştirmeye bakışı, öğretmenlerin meslekle ilgili ekonomik ve toplumsal beklentileri; öğretmenlerin mesleğe yönelik algılarını, başarılarını ve motivasyonlarını etkilemektedir. Bu sebeple günümüzde eğitim kurumlarının ve eğitim kalitesini arttırmaya yönelik çalışmaların, ilk etapta öğretmen kalitesi ve öğretmen yetiştirme programları üzerine odaklanması gerekmektedir. Bu süreçte öğretmenlerin kendilerini değişen koşullara ve rekabete hazırlamaları ise öğretmen yetiştirmek açısından ulusal ve uluslararası boyutta önemli bir konu haline gelmiştir (Güven 2001).

Öğrenme aracı olan öğretmen, sadece öğreten değil, aynı zamanda eğiten kişidir. Bu süreçte sınav yapan, disiplin sağlayan, kişilik ve karakter oluşumunda rehberlik yapan, öğrenciye farklı konularda danışman olan, güvenilir ve toplumsal yönü olan katılımcı bir kişidir. Öğretmenlerin değerlendirilmesi sürecinde alan bilgisi, kişilik, mesleki yeterlikler, çevreye uyum, iletişim becerileri, bireyleri fiziksel, sosyal ve duygusal açıdan tanıyabilme yeterlikleri temel ölçütler olarak alınmıştır (Balc1 1991; Battal 2003; Çelikten \& Can 2003; Karagözoğlu 2003; Çelikten, Şanal \& Yeni 2005). Öğretmen adaylarının yetiştirilmesi sürecinde; mesleğe uygun adayların seçilmesi, öğretmen yetiştirme yaklaşımları, eğitim felsefesi yaklaşımları ve nihayetinde öğretmen adaylarının mesleki yeterlik kazanması aşamalarından bahsedilebilir. Bu ölçütlerin ne kadar takip edildiği tartı̧̧ma konusu olsa da, mesleki eğitimin verildiği eğitim fakülteleri ve lisans programlarının içeriği öğretmen yetiştirme açısından kritik evreler olarak nitelendirilebilir (Hammond \& Cobb 1996).

Nitekim öğretmen yetiştirme programları incelendiğinde alan bilgisi, meslek bilgisi ve genel kültür olmak üzere üç temel yeterliğin öğretmen adaylarına kazandırılması amaçlamaktadır (Aydın 2007). Öğretmen yetiştirme programlarında bu üç temel özelliğin bütünleştiricisi ve mesleki yeterliliğin sağlanmasında kritik rol oynayan bir diğer süreç ise uygulamalardır. Alan bilgisi ve meslek bilgisi derslerinin teorik düzeyden uygulamalı düzeye aktarılması aslında öğretmenlik mesleği açısından birçok yeterliğin eş zamanlı gerçekleşmesini sağlamaktadır. Öğretmenlik mesleği için hizmet öncesi uygulamalar son derece önemli kabul edilmektedir. Öğretmen adayları bu uygulamalar yoluyla çocukların öğrenme ve gelişim özelliklerini tanımayı, bireysel ve özel ihtiyaçlarını karşılayabilmeyi, öğrenme yaşantılarını organize edebilmeyi, eğitim sorunlarından haberdar olmayı kendi mesleki gelişimlerini izleyerek öğrenmektedirler (Senemoğlu 1992; Tok 2011). Ayrıca bu süreçte öğretmen adayları özgüven, 
başarabilme duygusu, mesleki sorunlarla başa çıkabilme, hitabet, çocukların gelişim özelliklerini tanıma, davranış geliştirme, eleştirel düşünebilme, yansitıcı gözlem yapabilme, pedagojik inançlarını geliştirebilme gibi birçok yeterliği deneyimleyebilmektedir. Shulman (1986) bu konuya pedagojik alan bilgisi kavramıyla açıklık getirmiştir. Alan bilgisinin ve pedagojik bilginin basit bir şekilde bir araya gelmesinin yeterli olmadığını düşünen Shulman, pedagojik alan bilgisinin oluşabilmesi için uygulamaların çok önemli olduğunu belirtmiştir. Carlsen (1999) ise, pedagojik alan bilgisini, öğretmenlik mesleğinin verimliliği ve etkinliği için en önemli öğe olarak göstermiştir. Ancak; sınıf yönetimi, ölçme ve değerlendirme, öğretim teknolojileri ve materyal tasarımı, özel öğretim yöntemleri, eğitim bilimine giriş gibi pedagojik formasyon derslerinin kuramsal ya da uygulamalı verilmesinin ortaya koyduğu farklar bu konudaki araştırma yetersizliğinden dolayı netleştirilememiştir. Aynı şekilde bu derslerin alan bilgisi dersleriyle aynı anda $\mathrm{m} 1$, yoksa alan derslerini takiben mi, verilmesi gerekliliğini ortaya koyan çalışmalar son derece sınırlıdır (Yıldırım 2013). Mevcut durumda önce teorik sonrasında ise uygulama süreci takip edilmektedir. Ancak bu uygulamaların, mesleki gelişimi ne şekilde etkilediği ve yaşanan sorunlarla ilgili bilgiler kısıtlıdır.

Sosyal bilgiler öğretmenliği lisans programı için de benzer sorunların yaşandığı görülmektedir (Yılmaz 2009). Sosyal bilgiler dersi 2004 yılından itibaren öğrenci merkezli, yansitıcı gözlem ve araştırma geleneğine dayanan bir formata dönüştürülmüş olmasına rağmen (MEB 2005), sosyal bilgiler lisans programının uygulanmasında sorunların olduğu görülmektedir. Bu sorunlar programın kendisinden kaynaklandığı gibi uygulanma şeklinden de kaynaklanmaktadır. Öğretim sürecinde teori ve pratik arasındaki dengenin kurulamaması ise, bu sorunlar arasında gösterilmektedir (Dube 2009; Y1lmaz 2008). Bu durumun nedeni olarak ise, yapılandırmac1 eğitim anlayışının ve öğrenci merkezli eğitimin fakültelerde hala anlaşılamadığı gösterilmektedir (Taş 2004). Garcia (2008) bu durumu; "okul nüfusunu oluşturan ögrenciler ihmal edildiği için etkili sosyal bilgiler ögretmenleri yetiştirilememektedir" şeklinde açılamıştır. Sosyal bilgiler lisans programında yaşanan bu uygulama sorununun öğretmen olarak göreve başladıktan sonra da birtakım problemlere neden olduğu görülmüştür. Öğretmenler teorik bilgilerini uygulamaya dönüştürmede ve gerçek okul ortamına uyum sağlamada zorluk yaşadıklarını belirtmektedirler (Yılmaz \& Tepebaş, 2011). Bu bilgilerden hareketle sosyal bilgiler lisans programında yer alan uygulama derslerinde; özellikle Özel Öğretim Yöntemleri, Okul Deneyimi ve Öğretmenlik uygulaması başta olmak üzere, yaşanan sorunlar ve çözüm önerilerinin literatüre kazandırılması faydalı olacaktır.

$\mathrm{Bu}$ açıklamalar doğrultusunda çalışmanın amacı, Sosyal Bilgiler Öğretmenliği Lisans Programı'nda yer alan derslerin uygulama boyutunda yaşanan sorunları, öğretmen adaylarının görüşlerine bağlı olarak incelemektir. Bu bağlamda;

- Uygulama derslerinde yaşanan sorunların neler olduğu ve niteliği,

- Uygulama derslerinde yaşanan sorunların mesleki yeterlik üzerine etkilerinin neler olduğu,

- Uygulama derslerinde yaşanan sorunların çözümü için nelerin yapılabileceği bu araştırmanın alt problemleridir.

\section{Yöntem}

Araştırmanın bu bölümünde çalışmanın deseni, katılımcılar, veri toplama aracı, geçerlik güvenirlik çalışmaları ve verilerin analizi başlıklarına yer verilmiştir.

\section{Araştırma Modeli}

Nitel araştırma yönteminin tercih edildiği bu çalışmada, durum çalışması deseni kullanılmıştır. Durum çalışmasındaki amaç belirli bir bütünlüğü oluşturan durumlardan birinin diğerleri 
üzerindeki etkisini tespit etmektir (Ersoy \& Yalçınoğlu 2013). Bu araştırmada durum çalışması kullanılmasındaki mantık ise; nitelikli bir sosyal bilgiler öğretmeni yetiştirmek için, Sosyal Bilgiler Öğretmen Yetiştirme Programının (SBÖYP) tamamlanmasının gerekliliği şeklinde açıklanabilir. $\mathrm{Bu}$ programın tamamlanabilmesi için öğretmen adaylarının 8 dönemlik süreç içerisinde teorik ve uygulamalı bir eğitimden geçirilmesi öngörülmektedir. SBÖYP'nın bir bütünlük içerdiği düşünüldüğünde bu bütünlüğü oluşturan unsurlardan birinin ise "uygulama" başlı̆̆ 1 olduğu söylenebilir. Bu sebeple araştırmada durum çalışması deseni kullanılmış ve öğretmen adaylarının uygulama derslerine yönelik görüşleri SBÖYP'nın tamamlayıcısı olan bir durum olarak ele alınmıştır.

\section{Katılımcilar}

Bu araştırmanın katılımcılarının belirlenmesinde amaçlı örneklem yöntemlerinden ölçüt örnekleme kullanılmıştır. Bu örnekleme yönteminde temel düşünce önceden hazırlanmış bir takım ölçütlerin tamamının çalışılmasıdır. Belirlenecek ölçütler araştırmacının kendisi tarafından hazırlanacağ1 gibi farklı araştırmacılar tarafından önceden hazırlanmış ölçütler de olabilir (Yıldırım \& Şimşek 2005). Katılımcılar gönüllülük esasına bağlı olarak sosyal bilgiler eğitimi 4. sınıf öğrencilerinden seçilmiştir. Katılımcıların 4. sınıf öğrencileri arasından seçilmesinin nedeni lisans programını tamamlamaya en yakın öğrenciler olmasıdır. Sürece katılmak isteyen katılımcıların 6'sı kız, 4'ü erkektir. Katılımcıların akademik başarı düzeyleri ise 2.39 ile 3.90 arasında (4'lük sisteme göre) yer almaktadır. Katılımcılara ilişkin bilgiler tablo 1'de verilmiştir.

Tablo 1. Katılımcılara ilişkin bilgiler

\begin{tabular}{|c|c|c|c|c|}
\hline Kod İsim & Cinsiyet & Yaş & Sinıf & Not Ortalaması \\
\hline Ayşe & Bayan & 23 & 4 & 2.48 \\
\hline Özge & Bayan & 22 & 4 & 3.35 \\
\hline Nilay & Bayan & 25 & 4 & 2.82 \\
\hline Fatma & Bayan & 22 & 4 & 3.11 \\
\hline Gülay & Bayan & 22 & 4 & 3.31 \\
\hline Ayşegül & Bayan & 24 & 4 & 3.12 \\
\hline Ali & Bay & 24 & 4 & 2.99 \\
\hline Ahmet & Bay & 23 & 4 & 2.39 \\
\hline Güner & Bay & 22 & 4 & 3.90 \\
\hline Tuna & Bay & 23 & 4 & 3.01 \\
\hline
\end{tabular}

\section{Veri Toplama Aracı ve Verilerin Toplanması}

Araştırmada veri toplama yöntemi olarak odak grup görüşmesi kullanılmıştır. Odak grup görüşmesinin tercih nedeni ise, belli bir konu ya da görüş üzerinden çoklu bakış açısı sağlamanın bireysel görüşmelerden daha fazla bilgi sağlayacağı ve çözüm önerilerinin olgunlaşması açısından sağlıklı olacağının düşünülmesidir. Odak grup görüşmeleri, özellikle katılımcıların belirli bir politika ve eğitim programının uygulanmasına ilişkin görüşleri gibi benzer deneyimler üzerinde daha faydalı olmaktadır (Ersoy \& Yalçınoğlu 2013). Odak grup görüşmesi katılımcıların kendilerini rahat hissedebilecekleri geniş bir oturma salonunda gerçekleştirilmiştir. Odak grup görüşmelerinde benzeşik grupların (yaş, cinsiyet, 1rk, cinsel yönelim vb.) daha verimli olacağı belirtilmiştir. Bu araştırmada katılımcıların cinsiyet yönünden farklılaştığı ancak aynı meslek grubu ve branştan olmalarının bu dezavantajı ortadan kaldırabileceği düşünülmüştür. Görüşme öncesinde katılımcılara görüşme süreci ile ilgili bir yönerge verilmiştir. $\mathrm{Bu}$ yönergede odak grup görüşmesi hakkında bilgi, görüşme süresi, görüşmenin 
konusu ve araştırmacı tarafindan katılımcılara yönlendirilecek sorulara yer verilmiştir. 110 dakikalık görüşme süreci ses kaydı cihazı ile kayıt altına alınmıştır. Veri toplamak amacıyla araştırmacı tarafından hazırlanan soruların konuyla doğrudan ilgili verileri toplayacak şekilde hazırlanmasına dikkat edilmiştir. Araştırma süreci, araştırma konusuyla ilgili temaları kapsayacak kadar geniş ve ilgisiz konuları içermeyecek kadar dar kapsamlı şekilde planlanmıştır. Görüşmenin planlanan şekilde yürütülebilmesi için araştırmacı görüşme sürecini moderatör olarak yönetmiştir. Görüşmeler belirtilen derslerin öğretimi sonrasında, dönem sonunda gerçekleştirilmiştir.

\section{Geçerlik ve Güvenirlik Çalışmaları}

Nitel araştırmada geçerlik; inandırıcılık ve aktarılabilirlik ile ilgili iken, güvenirlik ise; tutarlılık ve teyit edilebilirlik ile ilgilidir (Yıldırım \& Şimşek 2005). Araştırmanın geçerlik ve güvenirlik çalışmalarına ilişkin yapılan işlemler aşağıda açıklanmıştır;

Araştırmanın iç geçerliğini (inandırıcılığını) artırmak için odak grup görüşmesinde kullanılacak olan sorular belirlenmiştir. Bu süreçte, hem öğretmen adayları ile ön araştırmanın yapılması hem de alanyazın incelemesi sonucunda konu ile ilgili bir kavramsal bir çerçeve oluşturulmuştur. Sosyal bilgiler lisans programının uygulanması ve işlevselliğine ilişkin çalışmalardan hareketle araştırma soruları ve kapsamı netleştirilmiştir. Odak grup görüşmesi sonrası kişilerin söyledikleri yazılı hale dönüştürülmüş ve bu metin katılımcılara tekrar gönderilerek kontrol etmeleri istenmiş, böylece katılımcıların ifadelerini teyit etmeleri sağlanmıştır. Böylece görüşme sürecinde toplanan verilerin gerçek durumu yansıtması sağlanmıştır.

Araştırmanın dış geçerliğini (aktarıla bilirliğini) artırmak için araştırmanın yöntem sürecinde yapılanlar ayrıntılı bir şekilde açıklanmaya çalışılmıştır. Bu bağlamda, araştırmanın modeli, çalışma grubunun özellikleri ve özellikle seçilme yöntemleri, veri toplama aracı, veri toplama süreci, verilerin çözümlenmesi ve yorumlanması ayrıntılı bir şekilde açıklanmaya çalışılmıştır.

Araştırmanın iç güvenirliğini (tutarlığını) artırmak odak grup görüşmesi sürecinden elde edilen veriler doğrudan verilmiştir. Ayrıca görüşmede elde edilen veriler üzerinde araştırmacı ve nitel araştırma konusunda deneyimli bir öğretim üyesi ayrı ayrı kodlamalar yapmış ve kodlamalar karşılaştırılarak tutarlık oranı hesaplanmıştır. Güvenirlik için her iki araştırmacı tarafından yapılan kodlamalar üzerinde Güvenirlik= Görüş Birliği/Görüş Birliği+Görüş Ayrılı̆̆ $X 100$ formülü uygulanmıştır (Miles \& Huberman 1994). İki kodlayıcı arasında uyuşum yüzdesi \%90 olarak hesaplanmıştır. Araştırma konusuyla ilgili daha önceden yayınlanmış çalışmalar incelenmiş ve araştırma bulguları bu çalışmalar ile desteklenmiştir.

Araştırmanın diş güvenirliğini (teyit edilebilirliğini) artırmak için araştırmacı, süreçte yapılanları ayrıntılı bir biçimde tanımlamıştır. Süreç boyunca elde edilen ham veriler ve ses kayıtları incelenebilmesi açısından saklanmaktadır. Araştırma sürecinde elde edilen verilerin raporlaştırılması ve makale formatına getirilmesinden sonra, metin mezun olan katılımcılara tekrar gönderilmiş ve dönütler incelenerek son bir değerlendirme yapılmıştır.

\section{Verilerin Analizi}

Uygulamalı derslere yönelik yaşanan sorunların detaylı bir şekilde incelenmeye çalışıldığ araştırmanın verileri içerik analizi yöntemi kullanılarak bulgulara dönüştürülmüştür. İçerik analizi, kodlama yoluyla verilerin altında yatan kavramları ve bu kavramlar arasındaki ilişkileri ortaya çıkarmak amacıyla yapılmaktadır (Miles \& Huberman 1994; Yıldırım \& Şimsek 2005). İçerik analizi üç aşamada gerçekleştirilmiştir. Birinci aşamada odak grup görüşmesinden elde edilen ses kayıtları Word dokümanı haline getirilmiştir. İkinci aşamada bu Word dokümanları 
katılımcılara dağıtılarak sorulara verilen ortak ve farklı cevaplarda ve kayıtlarda bir yanlışlık olup olmadığı kontrol edilmiştir. Üçüncü aşamada ise, nitel araştırma konusunda deneyimli bir başka öğretim üyesi yazılı verileri kodlamıştır. Verilerin analizi esnasında ortaya çıkan temaların özellikle "uygulama" kavramı ile olan ilişkisi dikkate alınmaya çalışılmıştır.

\section{Bulgular}

$\mathrm{Bu}$ bölümde araştırmanın alt problemlerine bağlı olarak elde edilen bulgulara yer verilmiştir. Bu bağlamda bulgular kısmı, sosyal bilgiler öğretmen yetiştirme programında uygulamalı derslere yönelik sorunlar, bu sorunların meslek bilgisi yeterliğine etkisi ve çözüm önerileri doğrultusunda üç ana başlık altında incelenmiştir.

\section{SBÖYP'nda Uygulamalı Derslere Yönelik Sorun Oluşturan Durumlar}

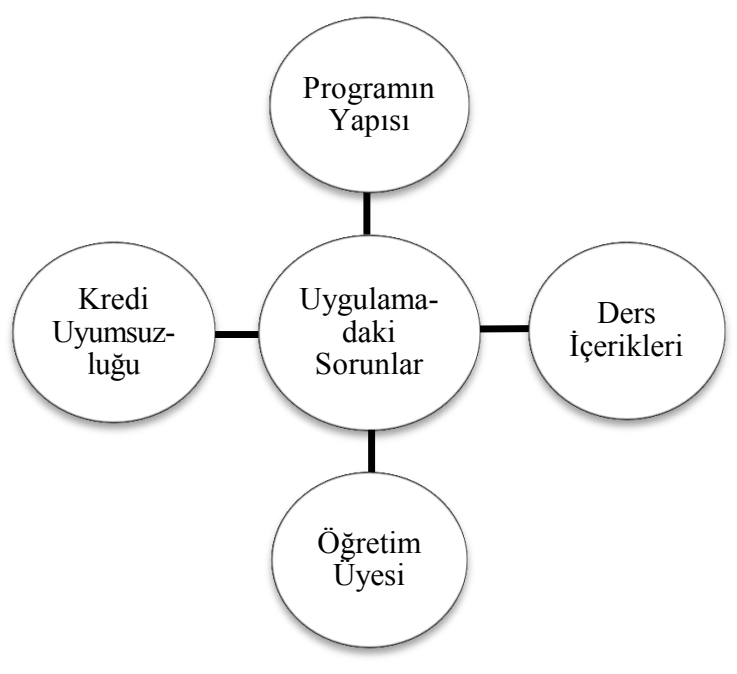

Fig. 1. Uygulama Derslerine Yönelik Sorun Oluşturan Durumlar
Öğretmen adaylarıyla yapılan odak grup görüşmesinden elde edilen verilerin analizi sonucunda uygulamalı derslerle ilgili olarak 4 farklı sorun tespit edilmiştir. Figür 1'de uygulamalı derslerle ilgili sorun oluşturan kategoriler verilmiştir. Öğretmen adayları bu sorun durumlarını kredi uyumsuzluğu, programın yapısı, ders içerikleri ve öğretim üyeleri olarak açıklamışlardır. Mesleğe hazırlık niteliği taşıyan 8 dönemlik sürecin teorik derslerle geçtiğini belirten öğretmen adayları, uygulamalı dersleri sadece konu anlatımları olarak görmemekte, özellikle mesleki formasyon derslerine ait bilgilerin uygulamalı olarak verilmesi gerektiğini dile getirerek teori ve uygulamada bir uyumsuzluğun olduğunu belirtmişlerdir. Ayrıca öğretmen adayları uygulama ders saatlerinin azlığının yanında öğre-

tim üyelerinin uygulama konularındaki yeterliği üzerine de görüş belirtmişlerdir. Kendi alanı dışında derse giren öğretim üyelerinin uygulama dersleri sürecinde sorun yaşadıklarını doğal olarak bu sorunlardan kendilerinin de etkilendiğini belirtmiş̧lerdir. Uygulamalı ders saatlerinin tek başına akademik bir anlamının olmayacağını düşünen öğretmen adayları, öğretim üyelerinin uygulamalı dersler konusundaki tecrübesinin de öğretmen yetiştirmek adına önemli olduğunu ifade etmektedirler. Özellikle öğretim üyelerinin uygulamalı derslerde öğretmen yetiştirme standartlarına uygun değerlendirme ve uygulamalı dersler için daha ciddi bir tavır almaları gerektiği görüşü dile getirilmiştir.

Bunlara ek olarak öğretmen adayları, uygulamalı ders saatlerinin 8 dönemlik eğitim sürecinde mezuniyete yakın dönemlerde okutulmasının mevcut şartlarda ciddi sorunlar oluşturduğunu dile getirmişlerdir. Özellikle okul deneyimi, öğretmenlik uygulaması ve öğretim derslerinin 7 ve 8 . dönemde yoğunlaştığını belirmişlerdir. Bu durumdan kaynaklı olarak mezun olma duygusu ve kamu sinavlarına hazırlık sürecinin de etkisiyle mevcut uygulamalı derslerden alınması gereken verimliliğin ciddi oranda azaldığını söylemektedirler. Uygulamalı ders saatlerinin yetersizliğini dile getiren öğretmen adayları, bu görüşlerinin ispatı olarak sosyal bilgiler lisans programının ortaokul sosyal bilgiler dersine ait kazanım, kavram, beceri ve değer boyutları açısından da yetersiz olduğunu belirtmişlerdir. Bu noktada lisans programının yapısı ve ders içerikleriyle ilgili bir sorun olduğunu da düşünülebilir. Sadece özel öğretim yöntemleri dersinin ve bu derse ayrılan zamanın bu konuları öğrenebilmek için yeterli olmadığını düşünen öğretmen 
adayları, kendilerini bu konuda yetersiz olarak görmektedirler. Konuyla ilgili olarak odak grup görüşmesi sürecinden bir alıntı aşağıda verilmiştir;

Araştırmacı: SBÖLP'ında uygulamalı derslere yönelik sorun olarak gördüğ̈̈n̈̈z durumlar nelerdir?

ÖA1: Zamanla ilgili problem olduğunu düşünüyorum. Yeterli değil hocam.

ÖA2: Kesinlikle yeterli değil. Koca 4 yllda sadece özel öğretim dersinde uygulama gördük.

ÖA3: Hocam onda da yetersizlik var yani, şimdi koca sinifta sadece bir kez ders anlatabildik.

ÖA3: Bide hocam arkadaşın dediğine katıllyorum. Üçüncü sınıfa gelene kadar hiçbirşey görmedik biz uygulamaya dönük olarak. Hepsi sona toplanmış bunların yayılması lazım bence.

ÖA4: Yani hocam yeterli değil. O kadar teorik dersin içinde uygulama fazla olmalı bence.

ÖA1: Evet mesela stajlar hepsi dördüncü sinıfta. Bide bunlar da sikıntılı hocam, takip edilmiyor.

ÖA2: Bizim burada gördüğ̈̈müz hocalarımızın uygulamadan anladığım artık bilmiyorum artı. Dersi bize anlattırmak oldu. Yani o konuda uygulama yerine geçmiyor.

ÖA7: Kesinlikle siz de çok iyi bilirsiniz ki insanlar gördüklerinin en az \%30'unu akıllarinda tutarlar ve daha verimli olur. Yani duyduğum bir şeyi öğrenciye aktarmaktansa gördüğ̈̈m bir şeyi öğrenciye daha iyi aktartrım ben. Bu da uygulamayla olur tabi ki.

Bunlara ek olarak öğretmen adaylarının ifadeleri sonucunda, belirtilen sorunların birbirinden bağımsız olmadıkları, eksikliği dile getirilen konuların birbiriyle bağlantılı olduğu söylenebilir. Sorun olarak görülen durumların birbirini etkilediğini dile getiren öğretmen adayları konunun bir bütün olarak ele alınması gerektiğini belirtmişlerdir.

\section{SBÖYP'ında Uygulamalı Derslerdeki Sorunların Mesleki Yeterlik Üzerine Etkisi}

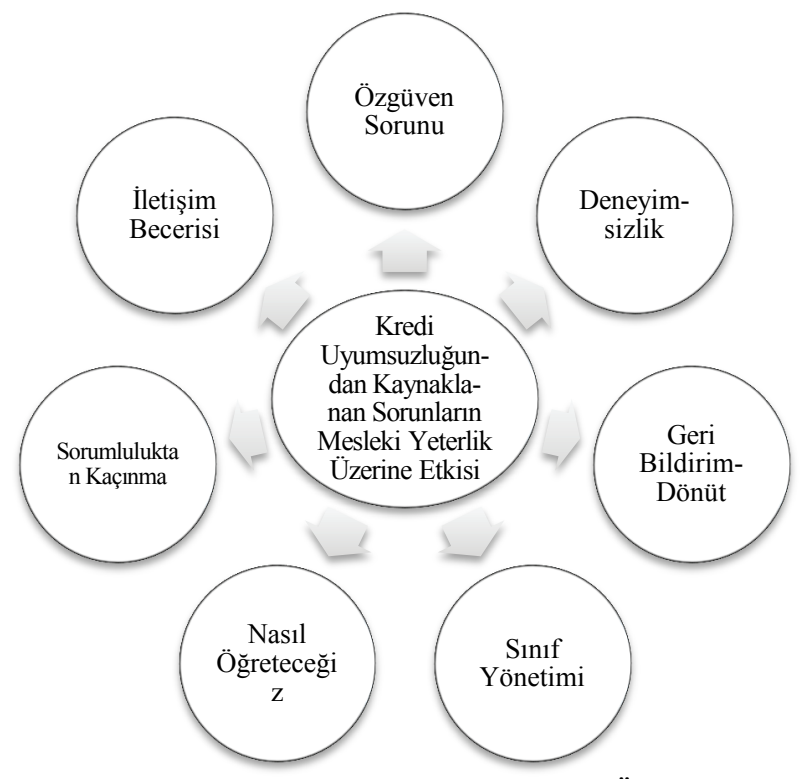

Fig. 2. Kredi Uyumsuzluğunun Mesleki Yeterlik Üzerine Etkisi
Figür 2'de kredi uyumsuzluğunun mesleki yeterlik üzerinde yaratmış olduğu sorunlar verilmiştir. Öğretmen adaylarının ifadeleri neticesinde elde edilen bulgulara bakıldığında kredi uyumsuzluğunun mesleki yeterlik üzerinde ciddi etkiler yaptığ görülmektedir. Figür 1 incelendiğinde nitelikli bir ögretmenin sahip olması gereken özelliklerin önemli bir kısmını görebiliriz. Özellikle sınıf yönetimi, iletişim becerisi, sorumluluk gibi öğretmenlik mesleğinin günümüz açısından vazgeçilmez ilkelerinin uygulamalı ders saatlerinin eksikliğinden dolayı yeterince içselleştirilemediği görülmektedir. Ayrıca öğrenilenlerin deneyimlenememesi, özgüven eksikliğine neden olmaktadır. Öğretmen adayları, eksik yönlerin tespit edilmesine yönelik olarak dönüt/geri bildi- 
rim alamamalarının nedenini uygulama eksikliğine bağlamaktadırlar. Öğrenci merkezli eğitim ve etkinlik temelli uygulamaların günümüzde tercih edilen öğretim metodu olduğu da düşünüldüğünde öğretmen adaylarının ifadeleri önemsenmelidir. Öğretmen adaylarının özellikle yapılandırmacı öğretmenler değiliz ifadeleri incelenmesi gereken konulardır.

Öğretmen adaylarının ifadeleri incelendiğinde öğretmenlik mesleğine olan inançlarına bağlı olarak bu ifadeleri kullandıkları söylenebilir. Öğretmen adayları, öğretmenlik mesleğinin kısa bir zaman dilimi içerisinde öğrenilemeyeceği ve teorik anlamda bilgi yüklemesiyle bu mesleğin gerektiği gibi yapılamayacağını dile getirmişlerdir. Bu açıklama öğretmen adaylarının öğretmenlik mesleğini önemsediklerini gösterirken bunun yanı sıra bu araştırma kapsamında kullandıkları ifadelerin de geçerliğini arttırmaktadır. Ayrıca öğretmen adaylarının ifadelerinde dikkati çeken farklı bir husus da mesleki yeterliğe ilişkin ifadelerin büyük oranda birbiriyle ilişkili olması ve uygulama derslerinin yetersiz olmasının yol açtığı olumsuzlukları genel olarak birbiriyle ilişkilendirmiş olmalarıdır. Öğretmen adayları yetersiz uygulamaların hem öğretim hem eğitim boyutlarında sorunları beraberinde getirdiğini ifade etmişlerdir. Öğrenilenlerin deneyimlenememesi sorunu beraberinde; eksik yönlerin tespit edilememesi, öğretim programı hakkında yeterince bilgi edinememe ve sınıf yönetimi becerisi eksikliklerine neden olmaktadır. Yetersiz uygulamalar öğretmen adaylarının özgüven algısını da etkilemektedir. Özgüven eksikliği sorunu ise sorumluluk alma korkusu, iletişim eksikliği gibi problemleri ortaya çıkarmaktadır. Öğretmen adaylarının ifadelerinden elde edilen bu bulgulara dayanak olması açısından görüşme metninden bir kesit aşağıda verilmiştir;

Araştırmacı: Uygulamalı dersler ve saatlerinin yetersiz olması mesleki yeterlik açısından hangi sorunların yaşanmasına sebep oluyor?

ÖA6: Hocam ilk olarak kendimize hiç güvenimiz yok, mesela ben stajda bu durum yüzünden çok zorlandım. Ders tarihti konuyu biliyorum ama nasıl anlatacağımı bilemedim yani.

Araştırmac1: Konuyu anlatmak için bir yöntem ya da teknik belirleyemedin mi?

ÖA6: Hocam onu da biliyorum ama nasıl nerden başlayacağımı hiç göstermediler ki bana, gelişi güzel anlattım yani öyle.

ÖA3: Şey vardı hocam mesela bizim 1. sınıfta sözlü anladım dersi vardı ben o dönem boyunca o derste $5 \mathrm{dk}$. Çıkıp konuştuk yani $5 \mathrm{dk}$. Çıkıp bir konu hakkında kendimizi ifade ettik.

Araştırmacı: Bu hangi yönünüzü geliş̧tirdi?

ÖA3: Hocam bişey gelişmedi, denetim yok ki, öğretmen nasıl anlatır, nasıl durur, bir arkadaş valla çıktı yemek tarifi verdi.

ÖA5: Hocam aslında birazda sorumluluk işi bu, tahtada ders anlatmak ama biz birinci sinıftan itibaren görseydik bunu belki farklı olurdu. Ama şimdi bunun acısını çekiyoruz, korku var yani.

Araştırmacı: Ne korkusu?

ÖA5: Bilmiyorum ama tahtada bize bişey oluyor, Araştırmact: Peki bu durum uygulama eksikliğinden mi kaynaklı?

ÖA5: Evet hocam bizim işimiz bence başından itibaren uygulama olmalı

Uygulamalı derslerde yaşanan sorunların mesleki yeterlik üzerinde ciddi etkilerinin olduğu bu ifadelere bağlı olarak söylenebilir. Ancak uygulamalı derslerdeki sorunların tek yönlü olarak mesleki yeterlik üzerinde etkilerinin olduğunu söylemek eksik olabilir. Öğretmen adaylarının da ifade ettiği gibi programın yapısı, ders içerikleri, öğretim üyelerinin derslere ilişkin yeterlikleri; uygulamadan kaynaklanan sorunların mesleki yeterlik üzerindeki etkisini arttırmış olabilir. 
Öğretmen adaylarının uygulamalı derslere yönelik sorun olarak belirttikleri durumlardan biri olan öğretim üyesi yeterliliğinin ise mesleki gelişim sürecine üç farklı etkisinin olduğu görülmektedir. Öğretmen adayları, öğretim üyelerinin uygulamalı derslere yönelik bakış açılarını eleştirmişlerdir. Öğretim üyelerinin teorik derslere oranla uygulamalı derslere gereken önemi vermediğini düşünen öğretmen adayları, bu durumun kendileri açısından sorun olduğunu ifade etmişlerdir. Derslerin teorik olarak anlatılan bölümlerinde öğrenilen bilgilerin uygulamalarda gereken önem verilmediği için somutlaştırılamadığı görülmektedir. Sorunla ilgili olarak; öğretim üyelerinin uygulamalı dersleri planlamada yetersiz kaldıkları ve bu yüzden de değerlendirme formu geliştiremedikleri görülmektedir. Bu durumun öğretmen adayları için de akademik anlamda boşvermişlik duygusu yarattığı bulgular arasındadır. Yeterli geri bildirim/dönüt alamayan öğretmen adayları öz değerlendirme yapamadıklarını da ifade etmişlerdir. Öğretmen adayları, deneyim ve uygulama sıklığına bağlı olarak gelişen öğretmenlik becerisinin, kendileri için daha mesleki eğitim sürecinde yaratıcıllğı kaybettirdiğini ifade etmişlerdir. Öğretmen adayları öğretim üyelerinin uygulamalı derslerde yaşadıkları sorunları, örnek olayların eksikliğine ve güncel mesleki sorunların uygulamalarla aktarılmamasına bağlamaktadırlar. Öğretmen adaylarının bu görüşlerine ilişkin veri örneklerinden bir kesit şu şekildedir;

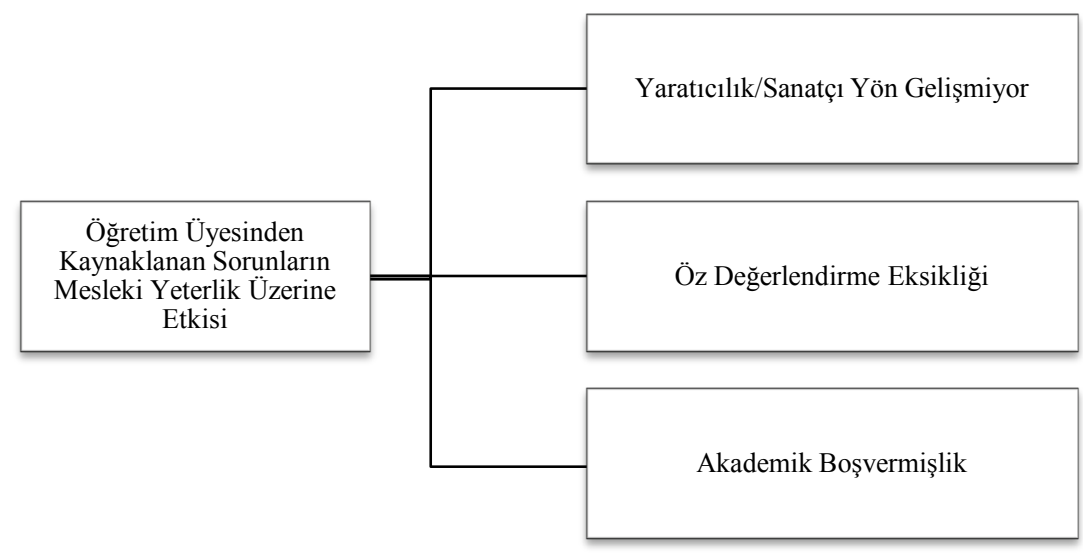

Fig. 3. Öğretim Üyesinden Kaynaklanan Sorunların Mesleki Yeterlik Üzerine Etkisi

ÖA3: Hocam bence eğitim fakültesi kapsamında genel olarak 1. sinıftan itibaren stajlar başlamalı son sene kalması ciddi bir yanlıştır. Saat süresi çok sınırlı bence 2. olarak bir gün veriyorlar birkaç hocalarımız gevip denetlemiyorlar. Denetlemedikleri için eksiklerimizi artılarımızı bilemiyoruz. İkinci bir yanlışta bu.

Araştırmacı: Onlar denetlemiyor diye sizde işinizi yapmıyor musunuz?

ÖA5: Hayır hocam bu işler biraz yönlendirmeyle oluyor, yoksa işimizi niye yapmayalım.

ÖA8: Hocam katıllyorum. Bir günde ögretmenlik ögrrenilmiyor. Ee gidiyoruz ama orda müdür kendi ayak işlerini yaptırtyor. Hadi şu sinavlarl oku, benim dersime gir benim daha ne işlerim var hadi zaten bir konu falan verdiği yok gidiyoruz. Pat diye sen biliyorsun zaten ya 
diyor bunları derse gidiyor. Tamam, gireyim de neye göre gireyim bir ön hazırlık yol giremiyoruz. Şeye geleneksel bir şekilde ders işleyip çıkıyoruz. Soru-cevap ya da bir ön bilgi ögrenelim. Öğrendiklerimiz kadarıla hani yapmaya çallşıyoruz ama verimli olmuyor. Hani şu dersi böyle anlatsan gibisinden bir eleştiride yok yani.

ÖA10: ...... Hocam teorik derslerimizde teorik derslerimizi veren hocalarımız alanında uzman değiller. Mesela bilim teknoloji, sosyal gelişme, bilimsel araştırma yöntemleri derslerini veren hocalarımız alanında uzman değiller. Uzman olması gerekiyor. Çünkü ileriye dönük bilimsem araştırma yapacakken bazı teknikleri yeterince bilmemiz lazım. Mesela bu konuda bize bir ödev verilseydi bizde buna göre hazırlaylp getirseydik yani bir şey yaptık ama yeterli olduğunu düşünmüyorum. Daha fazla uygulama gerektiriyor bu dersler.

Öğretim üyelerinin uygulamalı olarak okuttukları derslere yönelik bir geri bildirim sisteminin olmaması öğretmen adaylarının ifade ettikleri sorunların öğretim üyeleri tarafından görülmemesinin nedeni olabilir. Milli Eğitim Bakanlığının eğitim fakültelerine yönelttiği bir eleştirinin aslında bu konuyla da örtüştüğünü söyleyebiliriz. Mezun izleme sistemlerinin geliştirilememesi ya da tam anlamıyla işlevsel olmaması fakültelerin verdikleri eğitimin niteliğine ilişkin bir geri bildirim almalarını engellemektedirler. Bu durum ise öğretmen yetiştiren fakültelerin eksik yönlerini görmesini engellemektedir. Bu bağlamda eğitim fakültelerinde verilen eğitimin bir geri bildirim sistemiyle takip edilmesi sadece uygulamalı derslere yönelik değil öğretmen yetiştirme sürecine yönelik çoğu sorunu çözebilir. Öğretmen adayları buradaki temel problem durumunu alanı dışında derslere giren öğretim üyeleri olarak görmektedirler.

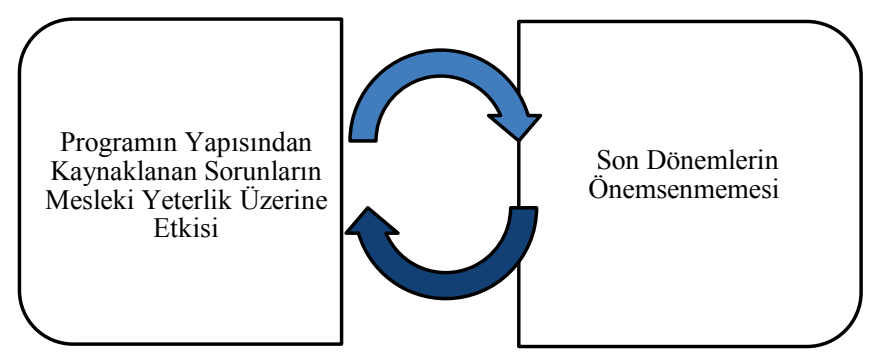

Fig. 4. Programin Yapısından Kaynaklanan Sorunların Mesleki Yeterlik Üzerine Etkileri
Figür 4'te ise uygulamalı derslerin yer verildiği dönemlere ilişkin bir sorun dile getirilmiştir. Öğretmen adayları özellikle staj uygulamalarının 7. ve 8. dönemde yer almasinın bu derslere olan ilgi ve alakayı azalttığ yönünde görüş belirtmiş̧lerdir. Nedeni sorulduğunda ise öğretmen adayları, son dönemlerde mezuniyet duygusu ve KPSS uğraşları yüzünden staj derslerine gereken önemi vereme-

diklerini ifade etmişlerdir. Staj dersi dâhil olmakla birlikte özellikle son dönemlere bırakılan uygulama derslerine gereken önemin verilmemesi ve öğretim üyelerinin de denetim yetersizliği yüzünden öğretmen adaylarında "nasılsa geçeriz" algısının oluştuğu söylenebilir. Öğretmen adayları, konuyla ilgili olarak bu derslere verilen notların ve raporların benzer olduğu yönünde ifadeler kullanarak görüşlerini savunmuşlardır. Öğretmen adaylarına son dönemde mutlaka bazı derslerin okutulması gerektiği söylendiğinde ise, bu dönemlere ağırlıklı olarak seçmeli ve teorik derslerin konulmasının sorunu çözeceğini ifade etmişlerdir. Ulaşılan bu bulgulara ilişkin görüşme kayıtlarından bazı örnekler ise şu şekildedir;

ÖA6: .........Bu derslerin son döneme bırakılması bizi çok etkiliyor, adam belki bu derse çok önme veriyor ancak KPSS var, alan sinavi felan dersken ne staj kalır adamın aklından ne ögrenci tek dert var AA ile nasıl geçerim. Bunun sebebi mevcut programın dizaynı ile ilgilidir bence 
Araştırmac1: Sonuç olarak ne diyebiliriz?

ÖA1: Öncelikle fakültede bu işlerin ciddiyetle ele alınması lazım. Ha tüm hocalarımız için değil ama büyük oranda sıkıntı var yani.

ÖA5: .....Sonra da bu öğretmen yetiştirme derslerinin tekrar elden geçmesi gerekir bence. Mesela bu stajın gözlem olanı öğretmenlik deneyimi 1 ya da 2 sinıftan itibaren dağttılmall. Formasyon dersleri 1 ve 2 ye çekilmeli özellikle sosyal bilgiler ögretimi mesela.

Figür 5'te uygulamalı derslerde içerik sorunu yaşandığına dair bir ifadeye yer verilmiştir. Öğretmen adayları özellikle sosyal bilgiler dersi ögretim programı ile ilgili içeriğin kendileri açısından sorun oluşturduğunu dile getirmişlerdir. $\mathrm{Bu}$ durum aslında öğrencilerin işlerini gerçekten önemsediklerini ancak öğretmen yetiştirme programına yönelik bazı sikıntılarının olduğunu göstermektedir. Öğretmen adayları ciddi anlamdaki teorik dersleri ilk etapta kabullendiklerini ancak programın sonlarına doğru

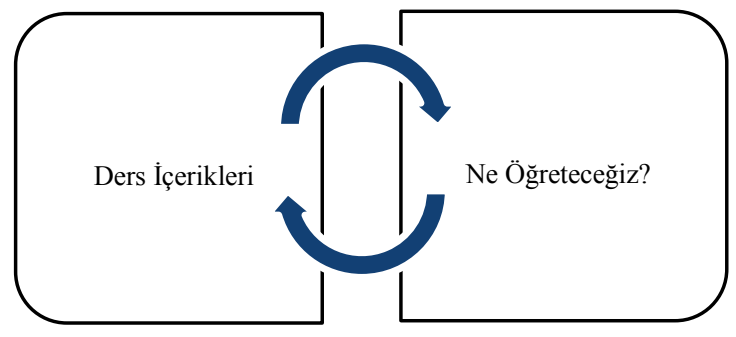

Fig. 5. Uygulamalı Ders İ̧eriklerinden Kaynaklanan Sorunların Mesleki Yeterlik Üzerine Etkileri

kavram, beceri, değer, kazanım ve etkinlik gibi bilgilerle karşılaştıklarında kafalarının karıştığını ifade etmişlerdir. Aslında öğrenci ifadelerinden anlaşılan; alan dersleriyle formasyon derslerinin gerektiği kadar ilişkilendirilememesi sorununa dayanmaktadır. Öğretmen adaylarının "ne öğreteceğiz" sorusuna cevap verememeleri yetersiz uygulamaların onlar üzerinde yarattığı endişeden kaynaklanıyor olabilir. Sonuç olarak 4 yıllık sürede alınmış ciddi bir alan bilgisi söz konusudur. Alan dersleri ve formasyon derslerinin bütünlük içerisinde olması bu durumun çözümü gibi görünmektedir. Yine öğretmen adaylarının ifadelerinden örnekler aşağıda verilmiştir;

.......̈̈A1: Yükle yükle nereye kadar bence ögretmenlikle ilgili özel bir dersin olması lazım. Hani ögretmenliğin öğretilmesi için yani. Gerçekten ögretmenlik ne demek yani sadece bilgi yüklemek mi demek. Son dönemde bize şu kavramı şu kazanımı öğreteceksiniz dediniz kaldık öyle bunlar ne diye.

ÖA6: Hocam mesela tarih derslerini işliyoruz hani ögretmenizim hocamız bizim o tarih derslerini işlerken birtakım teknikleri söylüyor. Ama bunları bence daha etkili bir şekilde kullanması lazım hocamızın da. Onu bize öyle göstermesi lazım. Hocam mesela lisede ben daha disiplinli bir okuldan geldim. Benim hocalarımın hepsi dersi anlatır giderdi. Buradaki hocalarımızın çoğu da öyle. Biz karşımızdakinden ne görürsek onu uyguluyoruz. Buradaki hocaların da ders işleme şeklini değiştirmeleri lazım hocam.

Araştırmacı: Nasil bir yol izlenmeli sizce?

ÖA5: Ben şöyle söyleyeyim hani hocam benim için 1.,2.,3. sınıf laylaylomdu yani. Öyle geçti diyeyim. Hani şu 1.sinıftan başladiğımızda olsaydl hiç olmazsa bize pat diye önümüze gelmez. Şu öğretimmişşu yöntemmiş şunu uygula olmuyor ki yani. Tamam verdin teoriyi aldim ben belki ama bunları kazanımla nasıl anlatıcam ben bilmiyorum. 


\section{SBÖYP'Indaki Uygulamalı Ders Sorunlarına Yönelik Çözüm Önerileri}

Yukarıda öğretmen adaylarının uygulamalı derslere yönelik yaşadıkları sorunlar ve bu durumların mesleki yeterlik üzerine etkilerine yer verilmiştir. Bu bölümde ise, öğretmen adaylarının uygulamalı derslere yönelik sorunların nasıl çözüleceğine dair önerilerine yer verilmiştir.

Tablo 2. Uygulamalı Derslerde Yaşanan Sorunlara Yönelik Öğretmen Adaylarının Çözüm Önerileri

Kredi Uyumsuzluğuna Yönelik Öneriler

\begin{tabular}{|c|c|}
\hline Çözüm önerisi 1: & $\begin{array}{l}\text { Osmanlı Tarihi, Türkiye Fiziki Coğrafyası, Antropoloji, Sanat ve Estetik, Türk Tarihi gibi } \\
\text { alan derslerinde öğretime esas } 1 \text { er saatlik uygulamaya yer verilmesi. }\end{array}$ \\
\hline Çözüm önerisi 2: & $\begin{array}{l}\text { Mesleki formasyon derslerinin birinci sınıftan itibaren ağırlıklı olarak verilmesi ve en azında } \\
\text { 1'er uygulama örneğinin öğretim üyesi tarafından öğretmen adaylarına verilmesi (Nasıl } \\
\text { öğreteceğimizi ne öğreteceğimizden daha önce öğrenmeliyiz) }\end{array}$ \\
\hline \multicolumn{2}{|c|}{ Öğretim Üyesi Sorununa Yönelik Öneriler } \\
\hline Çözüm önerisi 1: & Öğretim elemanlarının, alanları dışındaki derslere girmemesi \\
\hline Çözüm önerisi 2: & Uygulamalı derslere yönelik denetim ve ciddiyeti arttırmaları \\
\hline Çözüm önerisi 3: & $\begin{array}{l}\text { Uygulamalı derslere giren öğretim elemanlarının mesleğe yönelik örnek olaylar ve gerçek } \\
\text { yaşam durumlarını analiz etmeleri }\end{array}$ \\
\hline Çözüm önerisi 4: & Uygulamalı derslerde öğretmen adaylarına olabildiğince uygulama yapma şansı tanınmalı \\
\hline \multicolumn{2}{|c|}{ Programın Yapısına Yönelik Öneriler } \\
\hline Çözüm önerisi 1: & Özel Öğretim Yöntemleri Dersi I ve II'nin 1, 2 ve 3. sınıfta yer alması \\
\hline Çözüm önerisi 2: & $\begin{array}{l}\text { Staj derslerinin 1. sınıftan itibaren yapılandırılması ve özellikle okul deneyimi dersinin farklı } \\
\text { dönemlerde ve } 2 \text { 'şer saatlik uygulamalar halinde gerçekleştirilmesi }\end{array}$ \\
\hline Çözüm önerisi 3: & $\begin{array}{l}\text { Öğretmenlik uygulaması dersinin sadece rapor yazma etkinliği olmaktan çıkarılması ve } \\
\text { özellikle 4. sınıfın ikinci döneminde yer almaması. }\end{array}$ \\
\hline \multicolumn{2}{|c|}{ Ders İçeriklerine Yönelik Öneriler } \\
\hline Çözüm önerisi 1: & $\begin{array}{l}\text { Uygulamalı derslerde teorik içeriğin etkinlik örnekleriyle bütün olarak verilmesi. Yani bu } \\
\text { durumda yapılandırmacılık dediğimiz; bilgiyi uygulamayla yapılandırma sürecini de } \\
\text { gerçekleştirmiş oluruz. }\end{array}$ \\
\hline Çözüm önerisi 2: & $\begin{array}{l}\text { Teorik derslerde verilen bilgiler, sosyal bilgiler dersi müfredatıyla tamamen uyumlu bir hale } \\
\text { getirilmeli. }\end{array}$ \\
\hline Çözüm önerisi 3: & $\begin{array}{l}\text { Sosyal bilgiler dersi müfredatı içerisinde yer alan kavram, beceri, değer öğretimi sürecine } \\
\text { yönelik teorik ve uygulamalı derslerin içerikleri arttırılmalı }\end{array}$ \\
\hline
\end{tabular}

Tablo 2'de katılımcıların sosyal bilgiler lisans programındaki uygulamalı derslere yönelik yaşanan sorunların çözümüne ilişkin önerilerine yer verilmiştir. Katılımcılar, uygulama saatlerinin arttırılması, uygulama derslerinin 8 döneme yayılması gerektiği, uygulama ders içeriklerinin sosyal bilgiler dersi müfredatı açısından zenginleştirilmesi ve alanda yetkin öğretim elemanlarının uygulama derslerine katılmaları gerektiğini dile getirmişlerdir. Katılımcılar, pedagoji derslerinin yanı sıra alan derslerine yönelik uygulama derslerinin de olması gerektiğini belirtmişlerdir.

\section{Sonuç ve Tartışma}

$\mathrm{Bu}$ araştırma, Sosyal Bilgiler Öğretmenliği Lisans Programında yer alan derslerin uygulama boyutunda yaşanan sorunları, öğretmen adaylarının görüşlerine bağlı olarak incelemeyi amaçlamıştır. Uygulamaya derslerine dönük muhtemel sorunların, mesleki yeterlik üzerinde yaratacağı olumsuzlukların neler olduğu ve çözüm önerilerinin de geliştirilmesi öğretmen 
adaylarının ifadelerine bağlı olarak incelenmiştir. Elde edilen bulgular neticesinde, sosyal bilgiler öğretmen adaylarının uygulama derslerine yönelik belirgin sorunlar yaşadığı tespit edilmiştir.

$\mathrm{Bu}$ sorunlar genel olarak; kredi uyumsuzluğu, ders içerikleri, öğretim üyesi ve programın yapısına bağlı olarak şekillenmiştir. Benzer sonuçlar, Yılmaz'ın (2009) çalışmasında da dile getirilmiştir. Yılmaz (2009) teorik ders saatlerinin fazlalığı, öğretim elemanlarının geleneksel ders metodları ve uygulama sürecinin zayıf olması nedeniyle sosyal bilgiler eğitiminde sorunların yaşandığını belirtmektedir.

Öğretmen adayları ilk olarak uygulama derslerinin yetersiz olduğu görüşünü belirtmişlerdir. Öğretmen yetiştirme programında uygulamalı derslerin ağırlıklı olması gerektiğini belirten öğretmen adayları, yeterli uygulama yapamadıkları için teorik derslerden de mesleki anlamda faydalanamadıklarını, öğrendikleri bilginin ezberden öteye gidemediğini dile getirmişlerdir. Öğretmen adaylarının bu görüşü Brandford'un (2000) ifadesiyle de örtüşmektedir. Brandford'a (2000) göre, mesleki gelişim; bireysel performansı arttırmayı, verimsiz uygulamaları düzeltmeyi, eğitim politikalarının uygulanması için zemin oluşturmayı ve değişimi kolaylaştırmayı amaçlamaktadır. Ayrıca uygulama saatlerinin arttırılmasının tek başına bir anlamının olmadığını, uygulama derslerinin içerik, uygulanma zamanı ve uygulanma şekliyle de tekrar planlanması gerektiği sonucuna ulaşılmıştır. Öğretmen adaylarının uygulama derslerine yönelik bu görüşlerinin, Shulman (1986) pedagojik alan bilgisi kavramıyla da ilişkili görülmektedir. Shulman (1986), konu alanı bilgisi ve pedagojik bilginin basit bir birleşim olmadığını ifade ederek, pedagojik alan bilgisinin oluşabilmesi için alan bilgisi ve pedagoji bilgisinin zaman, içerik ve planlama açısından dengeli bir uygulama biçimi gerektirdiğini belirmiştir.

İçerik açısından sosyal bilgiler lisans programına yönelik (kavram, kazanım, beceri, değer etkinlik temelli) girdilerin arttırılması gerektiği çalışmanın diğer sonuçlarındandır. Sosyal bilgiler dersi müfredatına ilişkin yeterli bilgi sahibi olmadıklarını belirten öğretmen adayları mesleğe başladıkları zaman bu durumun kendileri için dezavantaj oluşturacağını düşünmektedirler. Sosyal bilgiler lisans programı incelendiğinde öğretmen adaylarının görüşlerine hak verilebilir. Lisans programında sosyal bilgiler dersi müfredatını tanıtıcı tek dersin Özel Öğretim Yöntemleri Dersi olduğu görülmektedir (YÖK 2007). Uygulamalı derslerin içeriğinin tekrar planlanmasının yanında, bu dersleri okutan öğretim elemanlarının, öğretmen yetiştirme standartlarını dikkate alarak değerlendirme yapması gerektiği sonucuna ulaşılmıştır. Alan dışı öğretim elemanlarının uygulamalı derslere girmemesi gerektiğini belirten öğretmen adayları bu durumun derslerin takibi ve verimliliği açısından kendilerini zor durumda bıraktıklarını ifade etmişlerdir. Son olarak uygulamalı derslerin okutulduğu dönemlerin değiştirilmesi gerektiği sonucuna ulaşılmıştır. Özellikle öğretmenlik deneyimi, öğretmenlik uygulaması, özel öğretim yöntemleri ve seminer derslerinin birinci sınıftan itibaren yayılması gerektiği belirtilmiştir. Bu konuda benzer bir önerinin Aras ve Sözen (2012) tarafından da yapıldığı görülmektedir. Bu durumun öğretmen adaylarını iki yönden etkilediği görülmüştür. Birincisi KPSS sınavına yönelik hazırlıklardan dolayı özellikle uygulamalı derslerde verimliliğin düştüğ̈̈, ikincisi ise son sınıf olmanın vermiş olduğu mezuniyet duygusunun öğretmen adaylarını akademik anlamda disiplinsizleştirdiği söylenebilir. KPSS ile ilgili bu bulguların Eraslan'ın (2009) çalışmasındaki sonuçlarla da örtüştüğü görülmüştür.

$\mathrm{Bu}$ sonuçlara bağlı olarak sosyal bilgiler lisans programının hala bilgi aktarıcı öğretmenler yetiştirdiği söylenebilir. Teori ve planlama açısından ilkokul programlarında yapılandırmacı eğitim anlayışının yer aldığını ancak uygulama boyutunda ciddi sorunların olduğu söylenebilir. Kendi teorik bilgisini uygulamaya koyma sorunu yaşayan öğretmenlerin, ortaokul öğrencileri için etkinlik temelli bir öğretim süreci planlayabilmesi de oldukça zordur. Nitekim Özbaş’ın 
(2012) yakın zaman içerisinde ortaya koyduğu çalışmada da sosyal bilgiler öğretmenleri kendilerini bilgi aktarıcısı olarak tanımlamışlardır.

Uygulamalı derslere yönelik bu sorunların doğal olarak mesleki yeterlik sürecine etkisinin olduğu söylenebilir. Bu etkiler bulgular kısmında verilmiştir. Burada önemli olan bu etkilerin öğretmen yeterlik standartlarıyla ne kadar ilişkili olduğudur. Özellikle günümüz öğretmen yeterlik standartları göz önüne alındığında; öğretmen adaylarının özgüven, sorumluluk alma, yaşam boyu öğrenme, gerçek yaşam durumlarını tartışabilme, yapılandırmacı öğretmen profili, öğrenciyi tanıma, sınıf yönetimi ve etkili iletişim gibi becerilere sahip olması gerekmektedir (Balc1 1991; Battal 2003; Çelikten \& Can 2003; Karagözoğlu 2003; Çelikten, Şanal \& Yeni 2005; Arslan \& Özpınar 2008). Araştırmanın bulgularına bağlı olarak uygulamalı derslerde yaşanan sorunların doğrudan bu standartları etkilediği görülmektedir. Bu sebeple yukarıda da ifade edildiği gibi alan bilgisi, genel kültür ve formasyon derslerinin uygulama dersleriyle bütünleştirilmesi gerekmektedir.

Öğretmen adaylarının ifadelerine bağlı olarak, uygulamalı derslere yönelik sorunların çözümüne ilişkin öneriler sunulmuştur. Öğretmen adaylarının önerileri incelendiğinde, alan dersleri, genel kültür dersleri ve formasyon derslerinin uygulamaya dönük kredilerinin olması gerektiği sonucuna ulaşılmıştır. Bu önerilerin geçerliğini arttıran bir diğer ifade ise öğretmen adaylarının sadece uygulama saatlerinin arttırılmasının yeterli olmayacağı görüşüdür. Bu sürecin, öğretim üyelerinin uygulamalı derslere yönelik planlamaları ve derslerin içeriğinin sosyal bilgiler öğretim müfredatına yakınlaştırılmasıyla tamamlanabileceği öngörülmüştür.

$\mathrm{Bu}$ araştırmanın konusu, öğretmenleri ve akademisyenleri de kapsayacak şekilde genişletilerek elde edilen sonuçların karşılaştırılması sağlanmalıdır. Daha fazla literatür bilgisi oluşabilmesi amacıyla konuyla ilgili araştırma sayısının arttırılması gerekmektedir. 


\section{KAYNAKÇA}

Aras S. \& Sözen S. (2012). “Türkiye, Finlandiya ve Güney Kore'de öğretmen yetiştirme programlarının incelenmesi”. X. Ulusal Fen Bilimleri ve Matematik Eğitimi Kongresi (27-30 Haziran 2012). Niğde.

Arslan S. \& Özpınar İ. (2008). "Öğretmen Nitelikleri: İlköğretim Programlarının Beklentileri ve Eğitim Fakültelerinin Kazandırdıkları”. Necatibey Eğitim Fakültesi Elektronik Fen ve Matematik Eğitimi Dergisi (EFMED) 2/1 (2008) 38-63.

Aydın R. (2007). Türkiye'de Eğitimle İlgili Yapılan Bilimsel Toplantılarda ve Millî Eğitim Şûralarında Ele Alınan Öğretmen Sorunları ile Millî Eğitim Bakanlı̆̆g'nın Politika ve Uygulamalarının Değerlendirilmesi (1980-2004). Ankara Üniversitesi Eğitim Bilimleri Enstitüsü Yayınlanmamış Doktora Tezi. Ankara 2007.

Balcı E. (1991). Öğretmenlerin Rolleri, Eğitim Sosyolojisi. Ankara 1991.

Battal N. (2003). "Cumhuriyet Üniversitesi’nin Açılışında Yaptığı Konuşma, Eğitimde Yansımalar”. VII. Çağdaş Eğitim Sistemlerinde Öğretmen Yetiştirme Sempozyumu, 13-14. Cumhuriyet Üniversitesi Kültür Merkezi. Sivas.

Blandford S. (2000). Managing Professional Development in Schools, Routledge Taylor ve Francis. London 2000.

Carlsen W. S. (1999). "Domains of teacher knowledge". Haz. J. Gess-Newsome \& N. G. Lederman. Examining pedagogical content knowledge: The construct and its implications for science education (1999) 133-144. Dordrecht.

Çelikten M. \& Can N. (2003). "Yönetici, Öğretmen ve Veli Gözüyle İdeal Öğretmen". Selçuk Üniversitesi Eğitim Fakültesi Dergisi 15 (2003) 253-267.

Çelikten M., Şanal M. \& Yeni Y. (2005). “Öğretmenlik Mesleği ve Özellikleri”. Erciyes Üniversitesi Sosyal Bilimler Enstitüsü Dergisi 19/2 (2005) 207-237.

Dube O. (2009). "Addressing current controversial 1ssues through the social studies curriculum: making social studies come alive". European Journal of Educational Studies 1/1 (2009) 25-34.

Duman T. (1991). Türkiye'de Ortä̈ğretime Öğretmen Yetiștirme. İstanbul 1991.

Eraslan A. (2009). "Finlandiya'nın PISA'daki Başarısının Nedenleri: Türkiye İçin Alınacak Dersler". Necatibey Eğitim Fakültesi Elektronik Fen ve Matematik Eğitimi Dergisi 3/2 (2009) 238-248.

Erçetin Ş. (2001). "Biz Akademisyenler Geleceğin Yüksek Öğretim Kurumlarını Yaratmaya Hazır miyız?". Kuram ve Uygulamada Eğitim Yönetimi, 25 (2001) 75-86.

Garcia J. (2008). "Reinventing social studies: By all means!”. Phi Delta Kappan 89/9 (2008) 660-663.

Güven İ. (2001). "Öğretmen Yetiştirmenin Uluslararası Boyutu". UNESCO 45. Uluslararası Eğitim Kongresi, Ankara: Milli Eğitim Yayınları. 2001.

Hammond L. D. \& Cobb V. L. (1996). “The Changing Context of Teacher Education”. Ed. F. B. Murray. Teachers Educator's Handbook (1996) 40-53. San Francisco: Jossey-Bass Publishers.

Karagözoğlu G. (2003). "Eğitim Sistemimizde Öğretmen Yetiştirme Politikamıza Genel Bir Bakış, Eğitimde Yansımalar". VII Çă̆daş Eğitim Sistemlerinde Öğretmen Yetiştirme Sempozyumu, Cumhuriyet Üniversitesi Kültür Merkezi, 10-12.

Karslı M. C., Yıldız K., Akgün N. \& Cerit Y. (2001). "Yeni Yönetim Teorilerinin Bazı Kavramları Açısından Eğitim Fakültelerinin Akreditasyonu Uygulamasının Analitik Olarak Değerlendirilmesi”. Kuram ve Uygulamada Eğitim Yönetimi $7 / 27$ (2001) 347-358.

M.E.B. (2004). Öğretmen Mesleğinin Genel Yeterlilikleri ve Özel Alan Yeterlilikleri Taslakları. Öğretmen Yetiştirme ve Eğitimi Genel Müdürlüğü. Ankara 2004.

M.E.B. (2005). İlköğretim Sosyal Bilgiler Dersi Öğretim Programı ve Kılavuzu. Ankara 2005

Miles M. B. \& Huberman M. A. (1994). An Expanded Sourcebook Qualitative Data Analysis. London 1994.

Özbaş Ç. B. (2012). "Sosyal bilgiler öğretmeni olarak, ben kimim?” Sosyal Bilgiler Öğretmenlerinin Mesleki Kimliklerine Yönelik Görüşlerinin Metafor Analizi Yoluyla İncelenmesi. Turkish Studies International Periodical for the Languages, Literature and History of Turkish or Turkic 7/2 (2012) 821-838. 
Özden Y. (1999). Öğrenme ve Öğretme. Ankara 1999.

Senemoğlu N. (1992). “İngiltere ve Türkiye'de İlköğretime Öğretmen Yetiştirme ve Türkiye'de İlköğretime Öğretmen Yetiştirmenin Geliştirilmesi İçin Öneriler". Türkiye'de İlköğretim Sempozyumu. Ankara 1992.

Sezal İ. \& Erkan S. (1997). "XXI. Yüzyıl Öğretmeni”. Uluslararası Dünya Öğretmen Eğitimi Konferansı, 27 Ağustos-2 Eylül 1995. Ankara.

Sözer E. (1991). “Türk Üniversitelerinde Öğretmen Yetiştirme Programlarının Öğretmenlik Davranışlarını Kazandırma Yönünden Etkililiği”. Anadolu Üniversitesi Eğitim Fakültesi Dergisi 4/1-2 (1991) 103-120.

Shulman L. S. (1986). "Those who understand: Knowledge growth in teaching". Educational Researcher 15/2 (1986) 4-14.

Taş M. A. (2004). "Sosyal Bilgiler Öğretmenliği Eğitimi Program Standartlarının Belirlenmesi”. Ankara Üniversitesi Eğitim Bilimleri Fakültesi Dergisi 37/1 (2004) 28-54.

Tok H. (2011). "Öğretmen Yetiştirmede Klinik Uygulama". Gaziantep Üniversitesi Sosyal Bilimler Dergisi 10/4 (2011) 1363-1375.

Yıldırım A. (2013). "Türkiye'de Öğretmen Eğitimi Araştırmaları: Yönelimler, Sorunlar ve Öncelikli Alanlar”. Eğitim ve Bilim 38/169 (2013) 175-192.

Yıldırım A. \& Şimşek H. (2005). Sosyal Bilimlerde Nitel Araştırma Yöntemleri. Ankara 2005.

Yılmaz K. (2009). "Lisans Düzeyinde Sosyal Bilgiler Eğitiminde Karşılaşılan Sorunlar ve Çözüm Önerileri; Öğretmen Adaylarının Görüşleri”. Ondokuz Mayıs Üniversitesi Eğitim Fakültesi Dergisi 27 (2009) 31-53.

Yılmaz K. (2008). "Social studies teachers' views of learner-centered instruction". European Journal of Teacher Education 31/1 (2008) 35-53.

Yılmaz K. \& Tepebaş F. (2011). "İlköğretim Düzeyinde Sosyal Bilgiler Eğitiminde Karşılaşılan Sorunlar: Mesleğine Yeni Başlayan Sosyal Bilgiler Öğretmenlerinin Görüşleri”. Çankırı Karatekin Üniversitesi Sosyal Bilimler Enstitüsü Dergisi 2/1 (2011) 157- 177.

YÖK (2007). Eğitim Fakültesi Öğretmen Yetiştirme Lisans Programları. Ankara 2007. 